\title{
BERPIKIR POSITIF DAN HARGA DIRI PADA WANITA YANG MENGALAMI MASA PREMENOPAUSE
}

\author{
Euis Sri Damayanti \& Alfi Purnamasari \\ Fakultas Psikologi \\ Universitas Ahmad Dahlan \\ Jalan Kapas No. 9 Yogyakarta \\ alfi_purnamasari@yahoo.com.
}

\begin{abstract}
The study aims to determine the relationship between positive thinking with self-esteem in women with premenopausal period. Subjects were premenopausal women who ages between 40-50 years old. The study used quantitative methods. This study used scale to get the data, namely Scale Positive Thinking and Self-Esteem Scale. The result showed a significant coefficient correlation with $r=0.465$. Positive thinking has about $21.6 \%$ explaining effect on the dependent variables and $78.4 \%$ influences by other factors. Majority participants in this study have medium level of esteem and positive thinking. Based on the result study, it can be concluded that there was a significant relationship between positive thinking with selfesteem in women who experienced a period of premenopausal. The higher positive thinking conducted by participant the higher their self-esteem, and vice versa.
\end{abstract}

Keywords: Positive Thinking, Premenopausal Period, Self-Esteem.

\begin{abstract}
Abstrak
Penelitian bertujuan untuk mengetahui hubungan antara berpikir positif dengan harga diri pada wanita yang mengalami masa premenopause. Subjek penelitian adalah wanita yang mengalami masa premenopause yang berusia antara 40-50 tahun. Metode penelitian menggunakan metode kuantitatif. Metode pengumpulan data menggunakan skala, yaitu Skala Berpikir Positif dan Skala Harga Diri. Hasil penelitian menunjukkan koefisien korelasi sebesar 0,465 . Sumbangan efektif atau besarnya pengaruh berpikir positif terhadap harga diri sebesar 21,6\% dan 78,4\% merupakan pengaruh faktor lain di luar berpikir positif. Kategorisasi subjek dalam skor berpikir positif dan harga diri berada dalam kategori sedang.
\end{abstract}


Berdasarkan hasil penelitian dapat disimpulkan bahwa ada hubungan yang sangat signifikan antara berpikir positif dengan harga diri pada wanita yang mengalami masa premenopause. Peningkatan berpikir positif diikuti dengan peningkatan harga diri, penurunan berpikir positif diikuti dengan penurunan harga diri.

Kata kunci : berpikir positif, harga diri, masa premenopause

\section{Pendahuluan}

Memasuki usia 40 tahun sering disebut juga masa transisi menjelang hari tua dan sering disebut masa dewasa madya. Pada masa dewasa madya sering muncul istilah power syndrome karena menjelang masa pensiun bagi yang bekerja yang sering disertai dengan stres karena munculnya generasi baru. Selain itu masa dewasa madya sering disebut masa berbahaya karena terkadang individu terlalu memaksakan diri dalam melakukan sesuatu. Pada masa dewasa madya diharapkan individu dapat mencapai tanggung jawab sosial dan dewasa sebagai warga negara, membantu anak belajar untuk bertanggung jawab, mencari pekerjaan pengisi waktu senggang, menghubungkan diri dengan pasangan hidup sebagai sosok individu, menerima dan menyesuaikan diri dengan perubahan fisik, mencapai prestasi yang memuaskan dan lain sebagainya (Hurlock, 1995).

Memasuki usia dewasa madya terjadi perubahan baik secara fisik maupun psikis. Perubahan fisik ditandai dengan psikomotorik yang menjadi kaku dan lamban serta muncul berbagai gejala penyakit, biasanya tulang pada sendi-sendi mulai rapuh atau sering disebut osteoporosis. Sedangkan perubahan psikis ditandai dengan mudah lupa, emosional dan motivasi untuk berperilaku yang positif juga menurun (Bromley, 1990).

Harapannya, semakin tua usia seseorang semakin matang emosinya tetapi kenyataannya banyak sekali individu menjadi labil ketika memasuki usia senja, terutama pada wanita. Ada yang mengatakan bahwa hidup dimulai pada usia 40 tahun, karena menurut teori pada usia 40 tahun emosi seseorang mencapai kestabilan (Kasdu, 2002).

Pada wanita yang memasuki dewasa madya yang usianya berkisar antara 40

45 tahun memasuki babak baru dalam rentang kehidupannya. Pada masa dewasa madya sebagian wanita mengalami masa premenopause, yaitu masa sebelum berlangsungnya perimenopause, yaitu sejak fungsi reproduksinya mulai menurun, sampai timbulnya keluhan atau tanda-tanda menopause. Semua wanita pasti akan mengalami masa premenopause. Hal ini merupakan tahap akhir proses biologi yang 
dialami wanita yang berupa penurunan produksi hormon seks wanita yaitu hormon estrogen dan progesteron (Kasdu, 2002).

Adapun tanda-tanda dari premenopause adalah terjadinya perubahan, baik perubahan fisik maupun perubahan psikis yang disebabkan oleh penurunan produksi hormon estrogen. Perubahan fisik meliputi ketidakteraturan siklus haid, perasaan panas (hot flushes), kekeringan vagina, perubahan kulit, keringat di malam hari, sulit tidur (insomnia), perubahan pada mulut, kerapuhan tulang, badan menjadi gemuk, dan munculnya gejala penyakit. Sedangkan perubahan psikis meliputi adanya kecemasan, ingatan menurun, mudah tersinggung, stres dan depresi (Kasdu, 2002).

Harga diri adalah dimensi evaluatif global dari diri yang ditandai dengan ciri tidak mengungkapkan pendapatnya terutama ketika ditanya dan melakukan rasionalisasi untuk kegagalannya, mencela diri dan merendahkan diri sendiri secara verbal, menghindari kontak fisik, terlalu membesar-besarkan prestasi dan penampilan fisik serta merendahkan orang lain dengan hal-hal negatif (Santrock, 1998).

Harga diri adalah dimensi evaluatif global dari diri. Harga diri juga diacu sebagai nilai diri atau citra diri (Santrock, 1998). Selain itu Santrock (2003) mendefinisikan harga diri sebagai penilaian yang menyeluruh dari diri. Harga diri disebut sebagai gambaran diri. Harga diri juga didefinisikan sebagai evaluasi terhadap diri sendiri (James dalam Baron \& Byrne, 2003). Baron \& Byrne (2003) mendefinisikan harga diri sebagai evaluasi diri yang dibuat oleh setiap individu atau sikap seseorang terhadap dirinya sendiri dalam rentang dimensi positif-negatif. Menurut Worchel, dkk (Dayakisni \& Hudaniah, 2003) harga diri adalah komponen evaluatif dari konsep diri, yang terdiri dari evaluasi positif dan negatif mengenai diri sendiri yang dimiliki seseorang.

Menurut Brem \& Kassin (Dayakisni \& Hudaniah, 2003) harga diri berkaitan dengan cara seseorang memandang dirinya dalam kehidupan sehari-hari. Individu yang menilai dirinya positif cenderung bahagia, sehat, berhasil dan dapat menyesuaikan diri. Sebaliknya individu yang menilai dirinya negatif secara relatif tidak sehat, cemas, tertekan dan pesimis mengenai masa depannya dan cenderung gagal.

Seseorang yang mempunyai konsep diri negatif, lebih banyak melihat hal negatif dalam dirinya sehingga harga dirinya cenderung rendah. Seseorang yang mempunyai pengharapan diri yang terlalu tinggi dan tidak realistis serta terlalu yakin dapat mencapainya, akan dapat menurunkan harga diri (Bernard, 1991).

Individu yang mempunyai harga diri tinggi mempunyai konsep diri yang realistis dengan sebuah apresiasi, tidak hanya kualitas negatif tapi juga kualitas positif. Individu yang mempunyai harga diri tinggi mempunyai perasaan stabil yang tidak berubah dari waktu ke waktu dan situasi ke situasi. Individu merasa mampu ketika tujuannya 
tidak tercapai atau mendapat celaan atau penolakan dari orang lain (Bernard, 1991). Alwisol (2004) mengemukakan ada dua jenis harga diri, yaitu : (1) Menghargai diri sendiri (self respect), (2) Mendapat penghargaan dari orang lain (respect from other). Menurut Wyland (Lopez \& Snyder, 2003) harga diri terdiri dari tiga komponen utama, yaitu : (a) Komponen penampilan, (b) Sosial , (c) Fisik.

Menurut Brem \& Kassin (Dayakisni \& Hudaniah, 2003) individu yang mempunyai harga diri rendah memilki suatu sikap mengalah diri (self-defeating) yang dapat memperangkap individu ke dalam suatu lingkaran yang menyesatkan. Biasanya karena individu mengharapkan kegagalan, individu menjadi cemas, menunjukkan usaha yang sedikit atau kecil dan menghilangkan tantangan-tantangan penting dalam kehidupan individu. Kemudian ketika individu gagal melakukannya, individu yang harga dirinya rendah cenderung menyalahkan diri sendiri dan pada gilirannya hal tersebut mengarahkan individu untuk merasa lebih tidak kompten.

Menurut Santrock (1998) ada beberapa ciri individu yang mempunyai harga diri yang rendah, yaitu :

1. Merendahkan orang lain dengan hal-hal negatif sehingga melihat lingkungan sekitar terlebih dahulu untuk bisa menerima orang lain.

2. Gerakan tubuh tidak sesuai konteks dan menghindari kontak fisik.

3. Terlalu membesar-besarkan prestasi, keterampilan dan penampilan fisik serta berbicara terlalu keras, tiba-tiba atau dengan nada suara yang dogmatis.

4. Merendahkan diri sendiri secara verbal, mencela diri dan memposisikan diri secara submisif.

5. Tidak mengemukakan pandangan atau pendapat terutama ketika ditanya dan melakukan rasionalisasi ketika gagal melakukan sesuatu.

Menurut Bernard (1991) ada beberapa ciri dari individu yang mempunyai harga diri rendah, yaitu :

1. Cenderung menarik diri dari lingkungan dan mempunyai kesulitan dalam menjalin persahabatan.

2. Cenderung menghukum diri dan pasif dalam menyesuaikan diri dengan tuntutan dan tekanan lingkungan.

3. Inferior, malu-malu, benci pada diri sendiri, kurang bisa menerima diri dan bersikap patuh sehingga kurang percaya diri untuk menghargai suatu penilaian atau kritik dari orang lain serta cenderung mengalah.

4. Menunjukkan tingkat kecemasan yang tinggi, depresi dan keluhan psikosomatis serta tidak tahan terhadap tekanan sosial.

5. Cenderung lebih tenang jika terjadi perbedaan pendapat yang menimbulkan 
personal attack dan bereaksi keras terhadap kritikan serta mempunyai kesadaran diri etika berbicara dengan orang lain.

6. Cenderung tidak terlihat sebagai anggota dari suatu kelompok, contohnya jarang tampil sebagai pemimpin.

Menurut Adler (Goble, 2004) individu yang harga dirinya kurang akan diliputi rasa rendah diri, rasa tidak berdaya, putus asa, tingkah laku neurotic. Menurut Santrock (1998) ada beberapa ciri individu yang mempunyai harga diri yang tinggi, yaitu:

1. Mempunyai kemampuan untuk memberi perintah atau petunjuk pada orang lain.

2. Mampu berkomunikasi dengan baik

Mampu berkomunikasi dengan baik meliputi memandang lawan bicara ketika mengajak atau diajak berbicara, menjaga kontak mata selama pembicaraan berlangsung dan memulai kontak yang ramah dengan orang lain.

3. Menyukai aktivitas sosial

Menyukai aktivitas sosial meliputi dapat bekerja secara kooperatif dalam kelompok dan mampu menjaga jarak antara dirinya dengan orang lain.

4. Berbicara dengan lancar ketika mengemukakan pendapat.

Menurut Bernard (1991) ada beberapa ciri individu yang mempunyai harga diri tinggi, yaitu:

1. Cenderung lebih efektif, aktif dan asertif dalam menyesuaikan diri dengan tuntutan lingkungan.

2. Menghormati diri sendiri, superior, rasa kebanggaan, penerimaan diri dan menyukai diri sendiri.

3. Cenderung mandiri dalam situasi yang menimbulkan konformitas dan percaya diri bahwa dirinya akan sukses sehingga cenderung untuk berpartisipasi dalam aktivitas yang mandiri.

4. Cenderung dikenal oleh teman sebayanya dan mampu menghargai dirinya dengan tepat.

5. Individu mempunyai keyakinan dan rasa percaya diri bahwa dirinya mempunyai kemampuan untuk menghadapi suatu kejadian sehingga kecemasannya hilang dan dapat menahan impilikasi negatif dari hukuman sosial.

6. Mampu bertahan melawan ancaman berdasarkan adekuasi dirinya.

Menurut Adler (Goble, 2004) seseorang yang cukup memiliki harga diri mempunyai cirri lebih percaya diri, lebih mampu, lebih produktif. Berdasarkan fenomena yang terjadi pada wanita yang mengalami masa premenopause, individu mempunyai harga diri yang rendah karena merasa cemas dan diliputi ketakutan adanya 
perubahan terhadap kondisi fisik bahwa dirinya akan menjadi tua dan tidak menarik. Selain itu ketakutan disebabkan karena pertumbuhan anak-anaknya yang sudah mulai dewasa dan telah meninggalkan rumah, sehingga individu merasa tidak berguna.

Berdasarkan hasil observasi dan wawancara yang dilakukan dengan penduduk Desa Kondangjajar dengan subjek lima orang wanita yang berusia sekitar $40 \quad 45$ tahun ditemukan bahwa individu mengalami masa premenopause yang ditandai dengan merasakan panas yang tiba-tiba disekitar leher, mudah tersinggung, ingatan menurun, siklus haid tidak teratur, perubahan pada mulut, inkontinensia urine dan perasaan panik yang tidak bisa dijelaskan. Selain itu terdapat fenomena bahwa wanita yang mengalami masa premenopause cenderung merasa tidak percaya diri dengan perubahan yang terjadi dalam dirinya terutama perubahan fisik sehingga individu berusaha untuk memperbaiki penampilan dengan menggunakan berbagai obat kecantikan untuk memperbaiki penampilan tanpa memperhatikan harga yang mahal dan resiko dari obat tersebut agar terlihat lebih muda dan menarik. Individu juga cenderung merendahkan diri sendiri karena merasa dirinya tidak menarik dan tidak berguna sehingga cenderung menghindari kontak fisik dengan orang lain dengan mengurangi aktivitas di luar rumah. Selain itu individu cenderung menolak ketika diminta untuk mengemban suatu tugas. Individu merasa tidak pantas dan tidak mampu untuk mengemban tugas tersebut dengan alasan merasa dirinya sudah tua dan masih banyak orang lain yang masih muda. Individu juga cenderung tidak berani mengugkapkan pendapat karena malu dan takut salah sehingga individu cenderung mengikuti pendapat orang lain. Fenomena tersebut menunjukkan harga diri yang rendah pada beberapa wanita yang mengalami masa premenopause yang merupakan penduduk Desa Kondangjajar.

Ada dua faktor yang mempengaruhi harga diri menurut Santrock (1998) yaitu: (1) Budaya, (2) Perbandingan sosial. Selain itu menurut Harter (Santrock, 1998) ada beberapa faktor yang mempengaruhi harga diri, yaitu : (1) Dukungan emosional, (2) Persetujuan sosial dalam bentuk persetujuan dari orang lain juga sangat mempengaruhi harga diri (Harter, dalam Santrock, 1998), (3) Prestasi (Bednar,Wels, \& Peterson, dalam Santrock, 1998), (4) Harga diri juga meningkat bila individu mengalami suatu masalah dan mencoba menghadapi masalah, bukan menghindari masalah (Lazarus dalam Santrock, 1998), (5) Berpikir positif.

Menurut Michener \& Delamater (Dayakisni \& Hudaniah, 2003), sumbersumber terpenting dalam pembentukan atau perkembangan harga diri adalah : (1) Pengalaman dalam keluarga, (2) Umpan balik terhadap performance, (3) Perbandingan sosial. 
Sedikides (Baron \& Byrne, 2003) menyatakan tiga kemungkinan motif dalam evaluasi diri. Individu dapat mencari self-assesment (untuk memperoleh pengetahuan yang akurat tentang dirinya sendiri), self-enhancement (untuk mendapatkan informasi positif tentang dirinya sendiri) dan self-verfiction (untuk mengkonfirmasi sesuatu yang sudah individu ketahui tentang dirinya sendiri). Motif mana yang paling sering aktif akan tergantung dari budaya dan kepribadian seseorang, serta situasi yang dihadapinya (Neter \& Wayment dalam Baron \& Byrne, 2003).

Banyak individu yang berbicara mengenai berpikir positif, tetapi rata-rata membuat suatu ketetapan bahwa berpikir positif merupakan suatu kebiasaan. Berpikir positif adalah pemusatan perhatian pada hal-hal positif dan menggunakan bahasa yang positif untuk mengekspresikan pikiran (Albrecht, 1980).

Menurut Cridder dkk (1983) memusatkan perhatian pada sisi yang positif dalam suatu keadaan yang dihadapinya akan membantu individu dalam menghadapi situasi yang mengancam dan menimbulkan stres. Berpikir positif dapat membuat individu memusatkan perhatian hal-hal positif dengan masalah yang dihadapinya, merasa tenang, rileks dan dapat menyesuaikan diri sehingga dapat mengatasi masalah yang dihadapi.

Menurut Albrecht (1980) berpikir positif terdiri dari dua aspek, yaitu:

1. Perhatian positif

Perhatian positif berhubungan dengan kemampuan individu untuk mengubah hal-hal negatif yang ada dalam dirinya menjadi hal-hal yang sifatnya positif, misal ketakutan untuk gagal diubah menjadi keberhasilan, perasaan cemas dalam menghadapi masalah diubah dengan memikirkan pemecahan masalah, frustrasi dengan masa depan yang suram diubah dengan harapan akan keberhasilan.

2. Ungkapan positif

Ungkapan positif berhubungan dengan harapan positif tentang diri individu. Ungkapan positif terdiri dari beberapa sub aspek di antaranya:

a. Afirmasi diri

Afirmasi diri berhubungan dengan menonjolkan kelebihan yang dimiliki oleh seseorang. Individu beranggapan bahwa dirinya mempunyai banyak kelebihan walaupun individu menyadari bahwa dirinya mempunyai kelemahan, akan tetapi kelemahan tersebut tidak menghambat penegasan dirinya sebagai individu dengan dasar pemikiran bahwa setiap individu sama berartinya dengan indvidu lain.

b. Pernyataan yang tidak menilai

Pernyataan yang tidak menilai menggambarkan keadaan diri apa adanya 
tanpa menutupi kelemahan dan tidak menilai keadaan individu.

c. Penyesuaian diri terhadap keadaan

Penyesuaian diri terhadap keadaan berhubungan dengan kesadaran seseorang tentang sesuatu yang sedang terjadi pada suatu keadaan dan kemampuan untuk menyesuaikan diri.

d. Harapan yang positif

Harapan yang positif berhubungan dengan anggapan individu bahwa dirinya mampu mencapai kesuksesan dan berusaha untuk mencapai kesuksesan tersebut dengan memotivasi diri secara verbal.

Ada beberapa ciri individu yang berpikir positif menurut Nald (2005), yaitu :

1. Pikirannya terbuka untuk menerima saran dan ide sehingga melihat masalah sebagai suatu tantangan dengan menghilangkan pikiran negatif mengenai berita yang belum pasti kebenarannya.

2. Tidak membuat alasan tetapi langsung membuat tindakan

3. Memperhatikan citra dirinya.

4. Menggunakan bahasa verbal dan non verbal yang positif

5. Menikmati hidup dengan mensyukuri hal yang dimilikinya.

Berdasarkan observasi dan wawancara yang dilakukan dengan penduduk Desa Kondangjajar dengan subjek lima orang wanita yang mengalami masa premenopause ditemukan fenomena bahwa individu yang mengalami masa premenopause cenderung cemas dalam menghadapi masalah terutama perubahan yang terjadi ketika mengalami masa premenopause. Individu cenderung tidak mau mengakui bahwa dirinya sudah berumur sehingga cenderung sulit untuk menyesuaikan diri dengan keadaan. Individu juga cenderung mempunyai pikiran negatif terhadap dirinya, orang lain serta lingkungan sekitar sehingga cenderung diliputi kecemasan dalam menjalani hidup. Selain itu individu merasa tidak mempunyai keistimewaan apa-apa dan merasa tidak ada lagi yang dapat dibanggakan dari dirinya. Menurut pengakuan seorang wanita yang mengalami masa premenopause, setelah memasuki masa premenopause dirinya menjadi lebih sensitif dan cenderung berpikir negatif terhadap sesuatu hal yang sebelumnya hal itu tidak terjadi pada dirinya. Fenomena tersebut menunjukkan berpikir positif yang rendah pada beberapa wanita yang mengalami masa premenopause yang merupakan penduduk Desa Kondangjajar.

Berdasarkan berbagai fenomena di atas peneliti tertarik untuk melakukan penelitian untuk melihat apakah ada hubungan antara berpikir positif dengan harga diri pada wanita yang mengalami masa premenopause? Hipotesis dalam penelitian ini ada hubungan positif antara berpikir positif dengan harga diri. Peningkatan berpikir 
positif diikuti dengan peningkatan harga diri, sebaliknya penurunan berpikir positif diikuti dengan penurunan harga diri.

\section{Metode Penelitian}

Karakteristik populasi penelitian adalah sebagai berikut :

1. Penduduk Desa Kondangjajar

2. Berjenis kelamin perempuan

3. Berusia antara 40-50 tahun

4. Telah mempunyai keturunan

5. Masih mempunyai pasangan hidup

Sampling yang digunakan yaitu area random sampling. Area random sampling adalah sampel yang menekankan pada jumlah subjek dari setiap area, dengan cara melakukan randomisasi terhadap indivdu untuk mengambil sampel sebanyak jumlah tertentu yang dianggap mereflesikan ciri populasi (Hadi, 2000).

Metode pengumpulan data dengan menggunakan skala yaitu Skala Berpikir Positif dan Skala Harga Diri. Pengujian reliabilitas skala mengunakan teknik konsistensi internal dari Cronbach. Sedang pengujian validitas mengunakan teknik validitas isi melalui metode professional judgment. Skala berpikir positif menghasilkan koefisien reliabilitas alpha sebesar $=0,867$. Sedangkan skala harga diri menghasilkan koefisien reliabilitas alpha sebesar $=0.897$. Berdasarkan hasil pengujian reliabilitas dan validitas isi, disimpulkan bahwa kedua skala penelitian valid dan reliabel untuk digunakan sebagai alat pengumpul data penelitian.

Metode yang digunakan untuk analisis data adalah analisis korelasi product moment untuk mencari hubungan antara variabel berpikir positif $(\mathrm{X})$ dengan variabel harga diri $(\mathrm{Y})$.

\section{Hasil dan Pembahasan}

Analisis data untuk mengetahui korelasi antara varaibel berpikir positif dengan harga diri dengan menggunakan analisis product moment. Berdasarkan hasil analisis data diketahui bahwa besarnya koefisien korelasi antara variabel berpikir positif dengan harga diri menunjukkan koefisien korelasi sebesar 0,465 dengan $p=0,000(p<0,01)$ sehingga dapat ditarik kesimpulan bahwa hipotesis yang berbunyi ada hubungan antara berpikir positif dengan harga diri diterima. 
Deskripsi data penelitian dapat dilihat pada Tabel 1.

Tabel 1. Deskripsi Data Penelitian

\begin{tabular}{ccccccccc}
\hline Variabel & \multicolumn{3}{c}{ Empirik (Skor X yang diperoleh) } & \multicolumn{3}{c}{$\begin{array}{c}\text { Hipotetik (Skor X yang } \\
\text { dimungkinkan ) }\end{array}$} \\
\cline { 2 - 9 } & XMax & Xmin & Mean & SD & XMax & XMin & Mean & SD \\
\hline Berpikir positif & 81 & 43 & 61 & 7 & 100 & 20 & 60 & 13 \\
Harga Diri & 83 & 44 & 57 & 9 & 100 & 20 & 60 & 13 \\
\hline
\end{tabular}

Berdasarkan hasil analisis diatas, dimana hipotesis yang berbunyi ada hubungan antara berpikir positif dengan harga diri dapat diterima dengan nilai koefisien sebesar 0,465 dengan $\mathrm{p}=0,000(\mathrm{p}<0,01)$ yang berarti bahwa korelasi antara berpikir positif dengan harga diri sangat signifikan. Semakin tinggi berpikir positif maka akan semakin tinggi harga diri, sebaliknya semakin rendah berpikir positif maka semakin rendah harga diri.

Wanita yang mengalami masa premenopause yang mempunyai pikiran positif beranggapan bahwa perubahan yang terjadi dalam diri individu baik fisik maupun psikis tidak harus dihindari atau disesali akan tetapi merupakan bagian kehidupan yang harus dihadapi. Wanita yang mengalami premenopause yang mempunyai pikiran positif cenderung dapat mengakui keadaan dan dapat menyesuaikan diri dengan cepat sehingga individu cenderung menyukai aktivitas sosial dan dapat bekerja secara kooperatif dalam kelompok serta mampu menjaga jarak antara dirinya dengan orang lain sehingga dapat disimpulkan bahwa individu tersebut mempunyai harga diri yang tinggi.

Wanita yang mengalami masa premenopause yang mempunyai pikiran positif cenderung lebih menggambarkan keadaan diri daripada menilai keadaan diri apa adanya tanpa menutupi kelemahan dan tidak menilai keadaan individu sehingga individu mampu berkomunikasi dengan baik, memandang lawan bicara ketika mengajak atau diajak berbicara, menjaga kontak mata selama pembicaraan berlangsung dan memulai kontak yang ramah dengan orang lain sehingga dapat disimpulkan bahwa individu tersebut mempunyai harga diri yang tinggi.

Wanita yang mengalami masa premenopause yang mempunyai pikiran positif cenderung mampu mengubah hal yang sifatnya negatif dalam dirinya menjadi hal yang positif dan berusaha untuk mencapai kesuksesan dengan memotivasi diri secara verbal sehingga individu dapat berbicara dengan lancar ketika mengemukakan pendapat sehingga dapat disimpulkan bahwa individu tersebut mempunyai harga diri yang tinggi.

Wanita yang mengalami masa premenopause yang mempunyai pikiran positif 
cenderung memusatkan perhatian pada kekuatan diri dan beranggapan bahwa setiap individu sama berartinya dengan individu yang lain sehingga individu dapat memberi perintah atau petunjuk pada orang lain, sehingga dapat disimpulkan bahwa individu tersebut mempunyai harga diri yang tinggi.

Sumbangan efektif atau besarnya pengaruh berpikir positif terhadap harga diri pada wanita penduduk Desa Kondangjajar sebesar 21,6\% selebihnya sebesar 78,4\% lainnya merupakan sumbangan dari faktor lain di luar berpikir positif.

Adapun faktor-faktor di luar berpikir positif yang diduga mempengaruhi harga diri di antaranya budaya, perbandingan sosial, dukungan emosional, prestasi dan persetujuan sosial. Harga diri juga meningkat bila individu mengalami suatu masalah dan mencoba menghadapi masalah, bukan menghindari masalah (Lazarus dalam Santrock, 1998). Apabila individu menghadapi masalah maka individu seringkali bersikap dan bertindak realistis, jujur dan tidak depensif. Hal ini akan menghasilkan self-generrated approval, yang menaikan harga diri. Sebaliknya, bila individu berusaha untuk menghindari masalah, maka harga diri individu akan menurun. Evaluasi diri yang tidak menguntungkan akan memicu penolakan, penipuan dan penghindaran dengan mencoba mengingkari kebenaran. Proses ini menghasilkan self-generrated approval sebagai suatu umpan balik kepada diri sendiri tentang kekurangan diri.

Peneliti dalam melakukan pengambilan data melakukannya secara individual sehingga peneliti dapat melihat secara langsung perilaku dan ungkapan yang dikemukakan oleh subjek ketika mengisi skala. Menurut pengamatan peneliti, subjek cenderung merespon setiap aitem. Subjek cenderung mengakui bahwa dirinya seperti yang tertulis dalam aitem.

Keterbatasan dalam penelitian yaitu kemampuan peneliti dalam membuat skala sehingga skala yang dibuat peneliti kurang dapat direspon dan dipahami maksud pernyataannya. Ada kemungkinan juga responden kurang serius dalam mengerjakan skala, walaupun sebelumnya peneliti telah mengantisipasi hal tersebut dengan meminta kesungguhan responden dalam menjawab pernyataan dan memberikan penjelasan bahwa bagaimanapun hasil yang diperoleh nantinya akan dijaga kerahasiaannya.

\section{Simpulan}

Ada hubungan positif yang sangat signifikan antara berpikir positif dengan harga diri. Peningkatan berpikir positif diikuti dengan peningkatan harga diri, penurunan berpikir positif diikuti dengan penurunan harga diri. Sumbangan efektif atau besarnya pengaruh berpikir positif terhadap harga diri pada wanita penduduk Desa Kondangjajar sebesar $21,6 \%$ selebihnya sebesar 78,4\% lainnya merupakan 
sumbangan dari faktor lain di luar berpikir positif.

\section{Daftar Pustaka}

Albrecht, K. G. (1980). Brain Power Learn to Improve Your Thinking Skill. New Jersey : Prenctice-Hall.inc.

Alwisol. (2004). Psikologi Kepribadian. Edisi Revisi. Malang : UMM Press.

Baron, R. A. \& Byrne. (2003). Psikologi Sosial. Jilid IEdisi Kesepuluh. Penerjemah : Ratna Djuwita, dkk. Jakarta : Erlangga.

Bernard, M. F. (1991). Taking The Stress Out of Teaching. Melborne Australia : Collins Dove.

Bromley, D.B.(1990). Behaviour Gerontology Center Issues in The Psychology of Aging. Chichester : New York : John Wiley \& Sons.

Cridder, A.B., Goothals, G.R, Kavanough, R.D and Solomon, P.R. (1983). Psychology. New York : Scott, Foresman and Company.

Dayakisni, T. \& Hudaniah.(2003). Psikologi Sosial Jilid I. Malang : UMM Press.

Goble, F. G. (2004). Ma hab Ketiga Psikologi Humanistik Abraham Maslow. Jakarta:Kanisius.

Hadi, S. (2000). Statistik. Jilid 2. Yogyakarta : Andi.

Hurlock, E.B. (1995). Psikologi Perkembangan Suatu Pendekatan Sepanjang Rentang Kehidupan. edisi kelima. Jakarta : Erlangga.

Kasdu, D. (2002). Kiat Sehat dan Bahagia di Usia Menopause. Jakarta : Puspa Swara.

Lopez, S. J \& Snyder, C.R. (2003). Positive Psychology Assessment A Handbook of Models and Measures. Washington, DC : American Psychological Association.

Nald, D. (2005). 10 Ciri Orang OrangBerpikirPositif. http:// www.groups.yahoo.com./group/pelaut. 14 September 2006.

Santrock, J. W. (1998). Adolesence. Seventh Edition. New York : Mc Graw Hill.

Santrock, J.W. (2003). Life Span Development Perkembangan Masa Hidup. edisi kelima. Jakarta: Erlangga. 